IMMUNOLOGICAL ASPECTS

\title{
Thermostability of IFN- $\gamma$ and IP-10 release assays for latent infection with Mycobacterium tuberculosis: A TBnet study
}

\author{
Thomas Blauenfeldt ${ }^{\mathrm{a}}$, Dirk Wagner ${ }^{\mathrm{b}}$, Martine Aabye ${ }^{\mathrm{c}}$, Jan Heyckendorf ${ }^{\mathrm{d}}$, Berit Lange ${ }^{\mathrm{b}}$, \\ Christoph Lange ${ }^{\text {d, e, f, g }}$, Martin Ernst ${ }^{d}$, Pernille Ravn ${ }^{\text {h }}$, Raquel Duarte ${ }^{\mathrm{i}, \mathrm{j}, \mathrm{k}, \mathrm{l}}$, \\ Clara Morais ${ }^{\mathrm{m}}$, Matthias Hoffmann ${ }^{\mathrm{n}}$, Otto D. Schoch ${ }^{\mathrm{o}}$, Jose Dominguez ${ }^{\mathrm{p}}$, Irene Latorre ${ }^{\mathrm{p}}$, \\ Morten Ruhwald ${ }^{\text {a, * }}$
}

a Department of Infectious Disease Immunology, Statens Serum Institut, Copenhagen, Denmark

${ }^{\mathrm{b}}$ Department of Infectious Diseases and Center for Chronic Immunodeficiency, Medical Center, University of Freiburg, Freiburg, Germany

${ }^{c}$ Department of Double Diagnosis, Mental Health Centre Sct. Hans, Roskilde, Denmark

d Division of Clinical Infectious Diseases, Research Center Borstel, Germany

e German Center for Infection Research Tuberculosis Unit International Health/Infectious Diseases, University of Lübeck, Germany

${ }^{\mathrm{f}}$ Department of Internal Medicine, University of Namibia School of Medicine, Windhoek, Namibia

${ }^{g}$ Department of Medicine, Karolinska Institute, Stockholm, Sweden

${ }^{\mathrm{h}}$ Department of Pulmonary and Infectious Diseases, Nordsjaelland Hospital, Hillerød, Denmark

${ }^{\mathrm{i}}$ Tuberculosis Outpatient Centre Vila Nova de Gaia, Portugal

${ }^{\mathrm{j}}$ Hospital Centre of Vila Nova de Gaia/Espinho, Portugal

${ }^{\mathrm{k}}$ Medical School, Porto University, Portugal

${ }^{1}$ Institute of Public Health, Porto University, Portugal

${ }^{m}$ Pulmonology Diagnostic Center Porto and Vila Nova de Gaia, Portugal

${ }^{n}$ Division of Infectious Diseases and Hospital Epidemiology, Cantonal Hospital St.Gallen, Switzerland

${ }^{\circ}$ Division of Pneumology, Department of Internal Medicine, Cantonal Hospital St.Gallen, Switzerland

p Servei de Microbiologia, Institut d'Investigació en Ciències de la Salut Germans Trias i Pujol, Universitat Autònoma de Barcelona, Ciber Enfermedades Respiratorias, Instituto de Salud Carlos III, Badalona, Spain

\section{A R T I C L E I N F O}

Article history:

Received 19 January 2015

Accepted 29 April 2015

\section{Keywords:}

IGRA

IP-10 release assay

Hyperthermia

Mycobacterium. tuberculosis

\begin{abstract}
S U M M A R Y
Introduction: Interferon- $\gamma$ (IFN- $\gamma$ ) inducible protein $10 \mathrm{kD}$ (IP-10) and IFN- $\gamma$ release assays (IGRAs) are immunodiagnostic tests aiming to identify the presence of specific cellular immune responses, interpreted as markers for latent infection with Mycobacterium tuberculosis. Incubation at higher temperatures could affect IFN- $\gamma$ and IP-10 responsiveness in order to improve the performance of IP-10 release assays and IGRAs.

Aim: The aim of this study was to assess the robustness of whole blood based IP-10 release assay and IGRAs and the effect of hyper-thermic incubation $\left(39^{\circ} \mathrm{C}\right)$ on the diagnostic accuracy of IP-10 release assay and IGRAs.

Results: We included 65 patients with confirmed pulmonary tuberculosis and 160 healthy controls from 6 European centres collaborating in the TBnet. In patients, IP-10 responses increased 1.07 (IQR 0.90-1.36) fold and IFN $-\gamma$ responses decreased 0.88 (IQR $0.57-1.02$ ) fold, with $39^{\circ} \mathrm{C}$ compared to $37{ }^{\circ} \mathrm{C}$ incubation temperature. At $37{ }^{\circ} \mathrm{C}$ IGRA sensitivity was $85 \%$ and IP-10 sensitivity was $82 \%$, whereas specificity was $97 \%$ for both tests $(p>0.8)$. These minor changes observed as a result of hyper-thermic incubation were not sufficient to impact IGRA and IP-10 release assay test performance.

Conclusion: The performance of IGRA and IP-10 release assays is robust despite variations in the incubation temperature between $37^{\circ} \mathrm{C}$ and $39^{\circ} \mathrm{C}$.
\end{abstract}

() 2015 Elsevier Ltd. All rights reserved.

\footnotetext{
* Corresponding author. Statens Serum Institut, Department of Infectious Disease Immunology, Building 81 - 3rd floor, Artillerivej 5, 2300 S., Copenhagen, Denmark. Tel.: +45 32683940.

E-mail address: moru@ssi.dk (M. Ruhwald).
}

\section{Introduction}

The World Health Organization's Post 2015 Global Tuberculosis (TB) strategy, calls for renewed research focus on improving the 
tools employed for predicting the risk of development of tuberculosis in persons at risk [1]. IFN- $\gamma$ release assays (IGRAs) are immunodiagnostic tests aiming to identify the presence of Mycobacterium tuberculosis specific cellular immune responses. In the absence of active TB, positive TST or IGRA responses are interpreted as markers for latent infection with $M$. tuberculosis [2-4]. Compared to tuberculin skin test (TST), IGRAs are more specific in BCG-vaccinated individuals, however IGRAs performance are generally not superior to the TST for the prediction of the development of TB in persons at risk [5-7]. Children and HIV-infected individuals with ongoing viral replication have increased risk of progression to disease, however IGRAs have shown poor performance in these groups $[8,9]$. IGRAs are highly susceptible to variability by numerous factors at multiple levels, including biological variability in the tested individual and technical variability from assay manufacturing, pre-analytical processing, and analytical testing $[2,10]$. Several attempts have been made to improve the performance of the immunodiagnostic tests including stimulation with antigens associated with mycobacterial dormancy or switching readout markers [11-13]. IP-10, a chemokine expressed in concert with IFN- $\gamma$ is a novel biomarker explored alternatively to the TST and IGRAs for the identification of individuals at risk for the development of TB [14-18]. IP-10 is expressed in 100 fold higher levels allowing for simpler readout platforms including lateral flow and potentially also improved detection of infection in young children and HIV-infected individuals [14-17].

In a recent proof-of-concept study we investigated another means of improving IGRA performance, incubation of samples at hyperthermic temperature $\left(39^{\circ} \mathrm{C}\right)$ [19]. Fever is an essential component of normal immune function in-vivo and the immunomodulatory effects of fever and febrile-range temperatures have been well categorized and include effects on cytokine expression, antigen presentation, and lymphocyte proliferation [20-24]. In a whole blood model we showed that IFN- $\gamma$ and IP-10 release was significantly increased at $39{ }^{\circ} \mathrm{C}$ compared to $37{ }^{\circ} \mathrm{C}$ incubation temperature in response to $M$. tuberculosis specific antigens and to mitogens in patients with TB. In a similar experiment in healthy controls, we demonstrated increased IP-10 release in response to Bacillus Calmette-Guérin (BCG) vaccine recall antigens, but failed to show an effect on IFN- $\gamma$ release in the same samples. The effects of hyper-thermic incubation were much more pronounced in TB patients and suggested that this simple approach could improve the diagnostic tests for infection with $M$. tuberculosis.

The aim of this study was to assess the robustness of IGRA and IP-10 release assays and potential effects of hyper-thermic incubation on IP-10 and IFN- $\gamma$ release and diagnostic potential in a cohort of patients with confirmed TB and healthy controls.

\section{Material and methods}

\subsection{Patient material}

Following ethical board approval and informed consent TB patients and healthy controls were enrolled at the University Hospital of Copenhagen, Denmark, the University Hospital of Freiburg, Germany, the Medical Clinic of the Research Center Borstel, Germany, the Tuberculosis Centre of Vila Nova de Gaia, Portugal, the Cantonal Hospital of St.Gallen, Switzerland and the Hospital German Trias i Pujol, Badalona, Spain, where investigators are collaborating in the TBnet (www.tb-net.org). We prospectively included patients with culture and or NAAT confirmed active TB who were $>18$ years of age and up to 1 month into TB treatment. Cases were included irrespective of HIV status and other immunosuppressive conditions. Controls with no ethnic, travel or other exposure, and no prior TB treatment or diagnosis were included among medical students and lab personnel. Demographics, HIV status, ethnic, travel and exposure history was noted for all patients and controls.

\subsection{Samples}

Whole blood was stimulated in the QuantiFERON ${ }^{\circledR}$ Gold in-tube (Qiagen, Venlo, The Netherlands; QFT) vacutainers. The QFT test comprises one vacutainer tube coated with $M$. tuberculosis specific peptides, one positive control tube coated with phytohemagglutinin and one uncoated negative control tube. Each participant had 2 sets of QFT-IT tests done. One was incubated at $37^{\circ} \mathrm{C}$ for $20 \mathrm{~h}$, the other for $20 \mathrm{~h}$ at $39{ }^{\circ} \mathrm{C}$. Samples were handled in parallel throughout. Following incubation, plasma supernatants from both sets were analysed per protocol with the QFT ELISA (Qiagen, Venlo, The Netherlands) and with an in-house IP-10 ELISA using pre-set cut-off for positive test [25]. Each participating centre had a dedicated incubator set at $39{ }^{\circ} \mathrm{C}$ with regular temperature checks throughout the study period.

\subsection{Ethical}

Inclusion of study participants was approved by the Ethical Committee of the Municipality of Copenhagen, Denmark (KF-01278477) and subsequently in all participating centers.

\subsection{Statistics}

IP-10 and IFN- $\gamma$ concentrations were compared with nonparametric paired tests. Test results were classified according to pre-set (QFT; Qiagen, NL [26]), or published (IP-10 [25]) algorithms. Test results were compared with McNemars test, a p-value of $\mathrm{p}<0.05$ was considered significant. Calculations and data management was done using SAS 9.2 (SAS institute, Cary, NC, USA) and GraphPadPrism 5.0 (GraphPad Software, Inc, La Jolla, CA, USA).

\section{Results}

\subsection{Patient material}

We included 65 patients with confirmed pulmonary TB by $M$. tuberculosis culture and 160 healthy unmatched controls from 6 European centres (Table 1). The controls were from Germany $(n=53)$, Spain $(n=9)$ and Denmark $(n=98)$ and the patients were from Germany $(n=37)$, Switzerland $(n=13)$ and Portugal $(n=15)$. The IP-10 and IFN- $\gamma$ results from the 98 Danish controls have previously been presented in another unrelated study [18]. Patients were predominantly male (44/65 (68\%) vs. 58/160 (36\%)), significantly older than the controls (41 (inter quartile range (IQR) 29-52) vs. 25 years (IQR 24-34), and 23/65 (35\%) of patients compared to $11 / 160$ (7\%) of controls were born outside Western Europe $(\mathrm{p}<0.001)$.

\subsection{Biomarker responses: $39^{\circ} \mathrm{C}$ vs. $37^{\circ} \mathrm{C}$}

In patients, IP-10 responses to antigen stimulation were significantly increased with $39{ }^{\circ} \mathrm{C}$ compared to $37{ }^{\circ} \mathrm{C}$ incubation temperature (median 1.07 fold (IQR 0.90-1.36), $\mathrm{p}=0.004$ ). In contrast, IFN $-\gamma$ responses were significantly reduced (median 0.88 fold (IQR $0.57-1.02$ ), $\mathrm{p}=0.002$ ) (Figure 1 ). In controls, the effects of hyperthermic incubation were minimal for both markers, although there was a discrete but significant decrease in the IFN $-\gamma$ response (Figure 2). IP-10 responsiveness to mitogen stimulation with incubation at $39^{\circ} \mathrm{C}$ was 1.11 fold increased (IQR $0.89-1.44, \mathrm{p}<0.001$ ), and not significantly different between cases and controls 
(Figure 3). As most IFN- $\gamma$ responses to mitogen stimulation overshot the range of the QFT ELISA (10 IU/ml), the impact of hyperthermia could not be accurately assessed.

\subsection{ROC curve analysis}

We compared the ROC curves of the 4 test modalities and found comparable AUCs 0.95-0.98 (Figure 4).

\subsection{Test results, concordance and changes in positivity rates: $39^{\circ} \mathrm{C}$ vs. $37^{\circ} \mathrm{C}$}

At $37^{\circ} \mathrm{C}$ QFT sensitivity was $56 / 65$ (85\%) and IP-10 sensitivity was $53 / 65$ (82\%), whereas specificity was $155 / 160$ (97\%) for both tests. Increasing the incubation temperature to $39{ }^{\circ} \mathrm{C}$ rendered comparable results: 52/65 (80\%) sensitivity for QFT and 53/65 (82\%) for IP10 , respectively; and specificity $156 / 158$ (99\%) for QFT and 153/157 (97\%) for IP-10, respectively ( $\mathrm{p}>0.57$ for all comparisons, Table 2 ).

At $37^{\circ} \mathrm{C}$ results from 3 patients (4\%) were concordant negative; results from 5 (8\%) were IP-10 positive and QFT negative, and results from 7 (11\%) were QFT positive and IP-10 negative/indeterminate. In the controls, results from 154 (96\%) were concordant negative, 4 results were concordant positive (3\%) and $1(1 \%)$ was IP10 positive, QFT negative. At $39^{\circ} \mathrm{C}$ results from 3 QFT and 1 IP-10 positive patients converted to negative, respectively $(\mathrm{p}>0.80$ compared to $37^{\circ} \mathrm{C}$ ).

\section{Discussion}

We assessed whether variations in temperature between $37{ }^{\circ} \mathrm{C}$ and $39^{\circ} \mathrm{C}$ influence the performance of whole blood based IGRA and IP-10 release assays for the diagnosis of infection with $M$. tuberculosis. Under normal incubation temperature of $37^{\circ} \mathrm{C}, \mathrm{IP}-10$ release assays and IGRAs performed similar across the 6 sites, and in agreement with previous publications $[11,25,27]$. Incubation at $39{ }^{\circ} \mathrm{C}$ increased IP-10 release and decreased IFN $-\gamma$ release in response to $M$. tuberculosis-antigens and mitogen stimulation in patients with confirmed TB. However, these differences did not influence test performance, as there was no significant difference in positive, negative and indeterminate results associated with

Table 1

Baseline.

\begin{tabular}{llll}
\hline & & Patients & Controls \\
\hline $\mathrm{n}(\%)$ & & 65 & 160 \\
Sex & & $44(68)$ & $58(36)$ \\
Age (IQR) & $41(29-52)$ & $25(24-34)$ \\
Country of birth & & \\
West Europe & & $32(50)$ & $151(94)$ \\
Africa & & $6(9)$ & $0(0)$ \\
Asia & & $8(13)$ & $3(2)$ \\
East Europe/Russia & & $16(25)$ & $1(1)$ \\
Americas & & $1(2)$ & $4(2)$ \\
Unknown & + & $1(2)$ & $1(1)$ \\
HIV & - & $3(5)$ & $0(0)$ \\
& unknown & $49(75)$ & $0(0)$ \\
Immunsuppressed & Yes & $5(8)$ & $160(100)$ \\
& No & $60(92)$ & $0(0)$ \\
Prior TB diagnosis & Yes & $10(15)$ & $0(0)$ \\
& No & $55(85)$ & $160(100)$ \\
Exposure to a TB patient & Unknown & $0(0)$ & $0(0)$ \\
& Yes & $13(20)$ & $10(6)$ \\
Stay in high endemic & No & $25(38)$ & $150(94)$ \\
area $>2$ months & Unknown & $27(42)$ & $0(0)$ \\
& Yes & $22(34)$ & $6(4)$ \\
& No & $28(43)$ & $153(95)$ \\
& Unknown & $15(23)$ & $1(1)$ \\
\hline
\end{tabular}

incubation temperature. The findings are in contrast to the literature [22,23] and our previous proof-of-concept study [19]. One study explored the impact of hypothermic $\left(35^{\circ} \mathrm{C}\right)$ incubation on QFT performance and found little impact [28], suggesting that the QFT performs consistently over a wide range of incubation temperatures $\left(35^{\circ} \mathrm{C}-39^{\circ} \mathrm{C}\right)$.

The current study was designed to validate the findings of that small study comparing 8 TB patients and 7 controls [19]. The initial study had two parts: A BCG-vaccine recall study in healthy controls, and $a$ TB diagnostic study comparing TB patients and healthy controls. The TB diagnostic part demonstrated higher levels of IFN- $\gamma$ and IP-10 responses (4.1 and 3.5 fold, respectively) to $M$. tuberculosis antigens after incubation at $39{ }^{\circ} \mathrm{C}$ versus $37^{\circ} \mathrm{C}$ in patients with confirmed TB and no change in controls; whereas the BCG-vaccine recall study showed a smaller, but significant 1.3 fold increase in IP10 release and no effect on IFN- $\gamma$ responses. The data shown here were comparable to our previous results from the BCG-vaccine recall model, but not the TB model. We did not see differences in the responses between the four centres contributing samples from TB patients, wherefore a technical bias seems unlikely in this study. The initial study was small and the risk of type 1 error is high, but we have no other obvious technical explanation for the differences between the two studies.

The concept that hyperthermia facilitates immune responses is well documented and it is established that fever-range temperature $39^{\circ} \mathrm{C}-40{ }^{\circ} \mathrm{C}$ is most favourable [20-24]. Detailed investigations in the mouse model as well as human studies have explored these effects of in vitro and whole body thermal stress showing increased adhesion of naïve $\mathrm{T}$ cells and lymphocyte extravasation of lymphoid organs [29], enhanced T cell proliferation and differentiation of naïve to effector $T$ cells [30,31], and enhanced responsiveness of both macrophages [32] and $T$ cells $[22,23,31]$. The effects are inducible with prolonged (days) and short (hours) thermal stress and maintained for at least $24 \mathrm{~h}$ [22,31-33]. The underlying mechanisms are incompletely understood, however the effects appear to affect $\mathrm{T}$ cells and antigen presenting cells independently [32,34] possibly through direct effects on the membrane fluidity [22] and induction of heat-shock proteins [35-37].

Studies exploring the effect of hyperthermia on cytokine release in cell mediated immune response assays, demonstrate augmented IFN- $\gamma$, IL- 2 , IL- 1 and TNF- $\alpha$ release upon challenge with peptides, PPD, and mitogens $[22,31,33,34]$. Except for one study using $2 \mathrm{~h}$ in vitro pre-incubation of whole blood at $39{ }^{\circ} \mathrm{C}$ before PBMC purification [22], no studies have explored the effects of hyperthermic incubation in a whole blood assay as done herein. It is tempting to speculate that our unexpected negative findings could at least in part be explained by the presence of erythrocytes during incubation. One of the effects of hyperthermic incubation is increased eryptosis (the suicidal death of erythrocytes) [38]. Eryptosis is triggered by thermal activation of $\mathrm{Ca}^{2+}$ permeable cation channels and $\mathrm{Ca}^{2+}$ influx, leading to cell shrinkage and scrambling of the cell membrane with phosphatidylserine exposure at the cell surface $[38,39]$. Eryptosis is further potentiated by ongoing inflammation as well as direct actions of rifampicin [40,41], suggesting a negative synergy influencing our findings in the TB patient group. Phosphatidylserine is a potent and directly acting inhibitor of $\mathrm{T}$ cell effector functions, effects which could be further debilitated by the drop in extracellular $\mathrm{Ca}^{2+}[42,43]$. A selective negative effect on $\mathrm{T}$ cell responses in the presence of hyperthermically augmented monocyte responsiveness [32] could explain the otherwise contraintuitive finding of increased IP-10 responses in spite of lower IFN- $\gamma$ release. However, this clinical study was not designed to explore these complex interactions. Further studies are needed exploring the interplay of eryptosis and cell mediated immunity. 

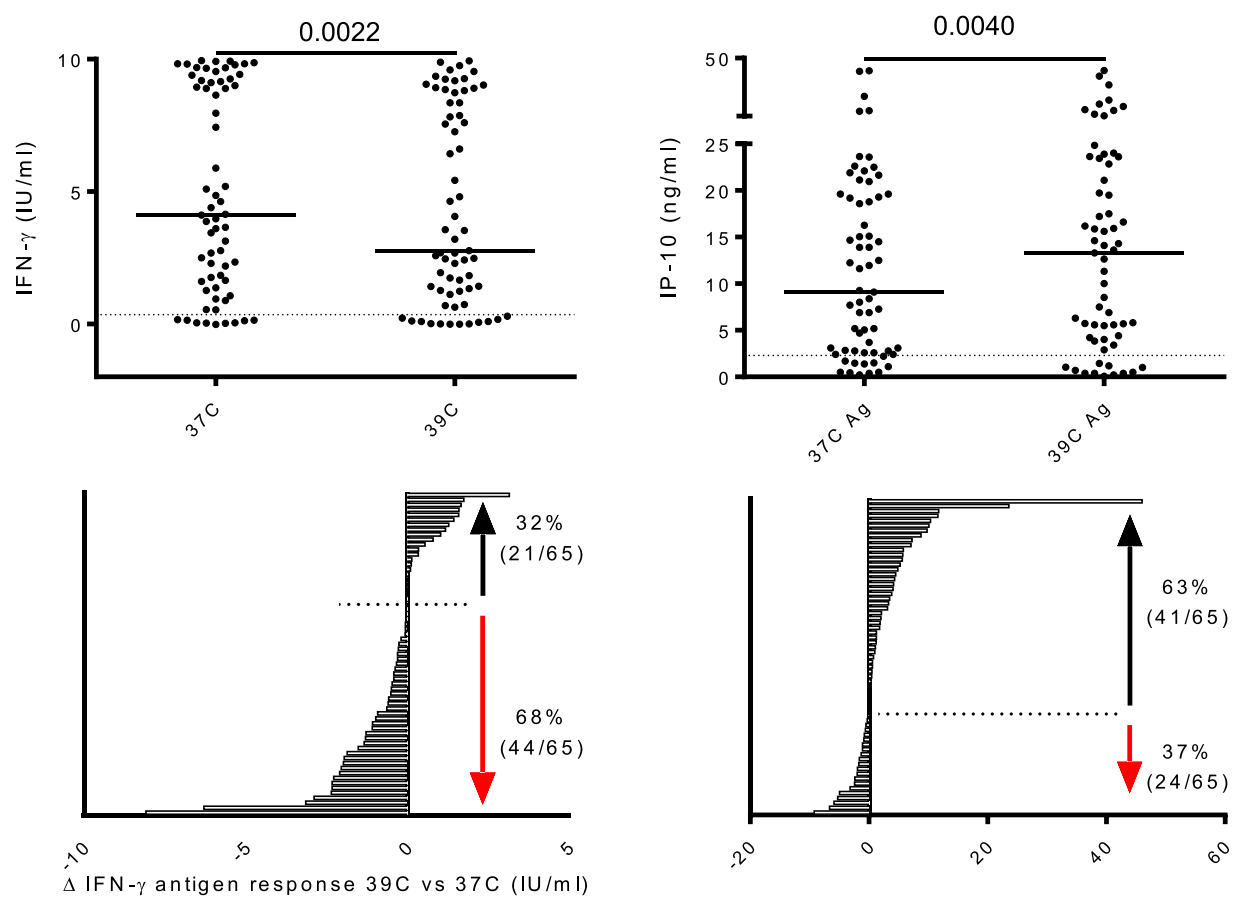

$\Delta \mathrm{IP}-10$ antigen response $39 \mathrm{C}$ vs $37 \mathrm{C}(\mathrm{ng} / \mathrm{ml})$

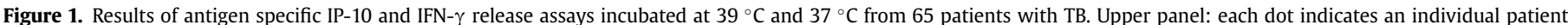

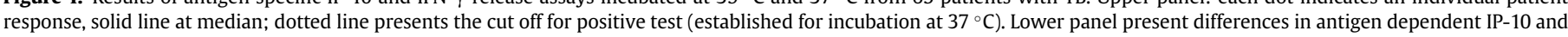

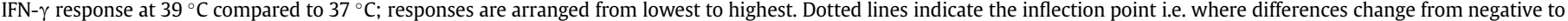
positive.

\section{Conclusion}

In conclusion, we assessed the impact of hyperthermic incubation on the magnitude of IFN- $\gamma$ and IP-10 release in response to
ESAT-6, CFP10 and TB7.7p4 peptide stimulation in a whole blood cell mediated immune response assay. Twenty hour incubation at $39^{\circ} \mathrm{C}$ compared to $37^{\circ} \mathrm{C}$ augmented the magnitude of IP-10 release, but had a negative effect on IFN $-\gamma$ release. The observe changes
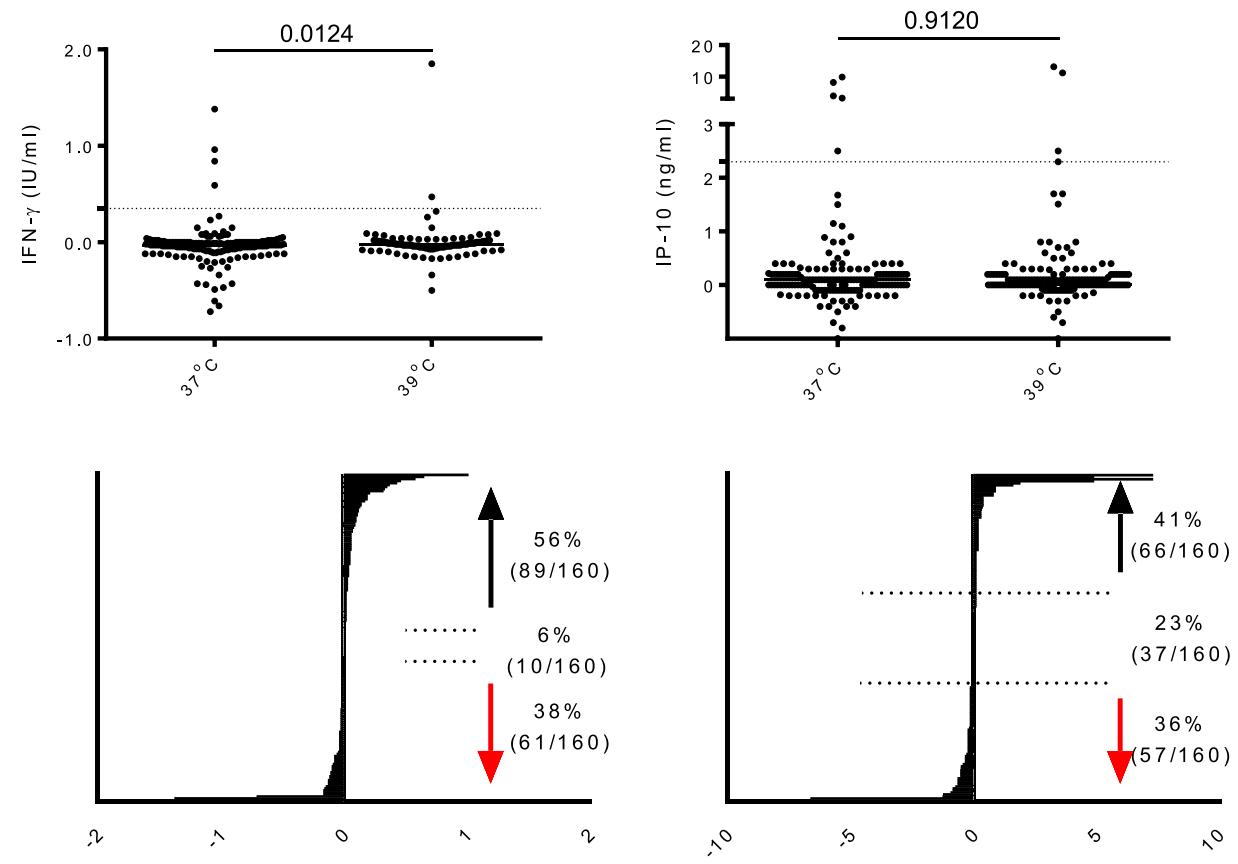

$\Delta \mathrm{IFN}-\gamma$ antigen response $39^{\circ} \mathrm{C}$ vs $37^{\circ} \mathrm{C}(\mathrm{IU} / \mathrm{m} \mathrm{I})$

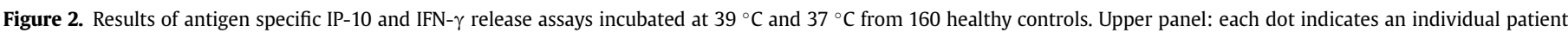

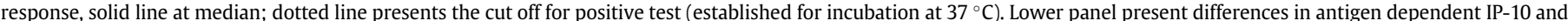

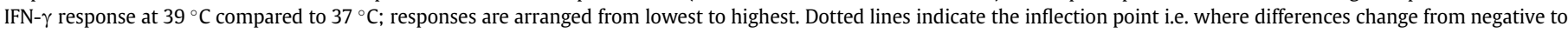
positive. 

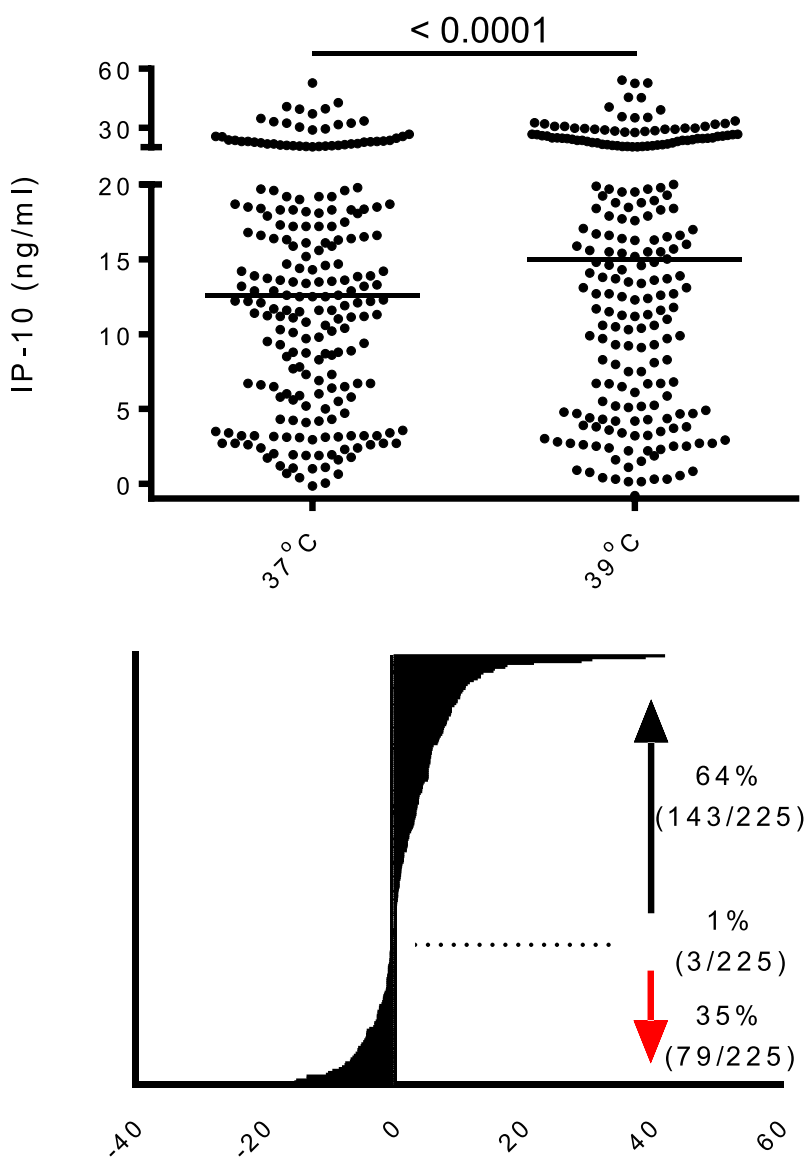

$\Delta \mathrm{IP}-10 \mathrm{~m}$ itogen response $39^{\circ} \mathrm{C}$ vs $37^{\circ} \mathrm{C}(\mathrm{ng} / \mathrm{m} \mathrm{I})$

Figure 3. Results of mitogen specific IP-10 release assays incubated at $39^{\circ} \mathrm{C}$ and $37{ }^{\circ} \mathrm{C}$ in 225 individuals (160 healthy controls and 65 TB patients). Upper panel: each dot indicates an individual response, solid line at median. Lower panel: Differences in mitogen dependent IP-10 response at $39{ }^{\circ} \mathrm{C}$ compared to $37{ }^{\circ} \mathrm{C}$ are arranged from lowest to highest. Dotted lines indicate the inflection point i.e. where differences change from negative to positive.

were not sufficient to impact IGRA and IP-10 release assay test performance, suggesting that the whole blood tests are robust and tolerate variation in the incubation temperature between $37{ }^{\circ} \mathrm{C}$ and $39^{\circ} \mathrm{C}$.

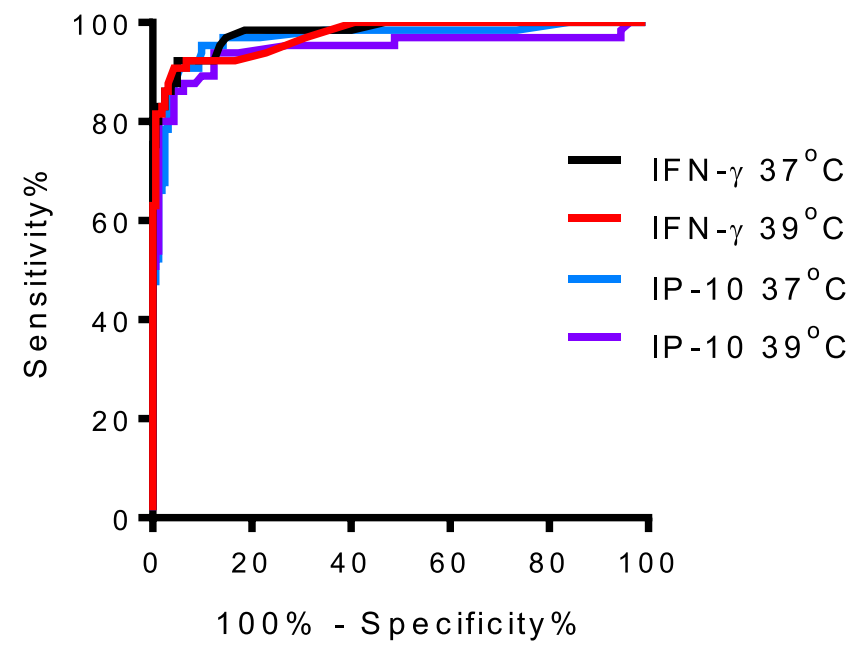

Figure 4. ROC curve analysis. Cut off independent comparison of the diagnostic potential of IP-10 and IFN-g release in response to antigen stimulation in QFT tubes.
Table 2

IP-10 release assay and OFT test results from 65 TB patients and 160 controls incubated at $37{ }^{\circ} \mathrm{C}$ and $39^{\circ} \mathrm{C}$. $\mathrm{n}(\%)$; Pos. denotes positive; neg. denotes negative; indet. denotes indeterminate.

\begin{tabular}{lllllll}
\hline & & $37^{\circ} \mathrm{C}$ & & $3{ }^{\circ} \mathrm{C}$ & \\
\cline { 3 - 4 } \cline { 6 - 7 } & & IP-10 & QFT & & IP-10 & QFT \\
\hline TB & Pos. & $53(82)$ & $56(85)$ & & $52(80)$ & $53(82)$ \\
& Neg. & $11(17)$ & $8(12)$ & & $11(17)$ & $11(17)$ \\
& Indet. & $1(2)$ & $1(2)$ & & $2(3)$ & $1(2)$ \\
Total & & 65 & 65 & & 65 & 65 \\
Control & Pos. & $5(3)$ & $4(3)$ & & $4(3)$ & $2(1)$ \\
& Neg. & $155(97)$ & $155(97)$ & & $153(96)$ & $156(98)$ \\
& Indet. & $0(0)$ & $1(1)$ & & $3(1)$ & $2(1)$ \\
Total & & 160 & 160 & & 160 & 160 \\
\hline
\end{tabular}

\section{Conflicts of interest}

TB and MR are employed by Statens Serum Institute, a governmental non-profit organization which hold and licences intellectual property on the use of ESAT-6, CFP10 and TB7.7 antigens for the diagnosis of latent infection with $M$. tuberculosis. MR and PR are registered as inventors on issued and pending patents filed by Copenhagen University Hospital, Hvidovre disclosing IP-10 as a biomarker for infection with M. tuberculosis.

\section{Acknowledgements}

The authors are grateful to Camilla Drabe, MD and Thomas Stig Hermansen, MD for help including donors in Copenhagen and Katja B. Carlsen for excellent technical assistance. $\mathrm{MH}$ received a grant by the Lungenliga St.Gallen to support the Swiss study site.

\section{References}

[1] WHO. Looking beyond. WHO; 2015, http://www who.int/tb/post2015 strategy/en/. accessed 10.06.14.

[2] Pai M, Denkinger CM, Kik SV, Rangaka MX, Zwerling A, Oxlade O, et al. Gamma interferon release assays for detection of Mycobacterium tuberculosis infection. Clin Microbiol Rev 2014;27:3-20. http://dx.doi.org/10.1128/CMR.0003413.

[3] Chee CB-E, Sester M, Zhang W, Lange C. Diagnosis and treatment of latent infection with Mycobacterium tuberculosis. Respirology 2013;18:205-16. http://dx.doi.org/10.1111/resp.12002.

[4] Mack U, Migliori GB, Sester M, Rieder HL, Ehlers S, Goletti D, et al. LTBI: latent tuberculosis infection or lasting immune responses to M. tuberculosis? A TBNET consensus statement. Eur Respir J 2009:33:956-73.

[5] Rangaka MX, Wilkinson KA, Glynn JR, Ling D, Menzies D, MwansaKambafwile J, et al. Predictive value of interferon- $\gamma$ release assays for incident active tuberculosis: a systematic review and meta-analysis. Lancet Infect Dis 2012;12:45-55. http://dx.doi.org/10.1016/S1473-3099(11)70210-9.

[6] Sester M, van Leth F, Bruchfeld J, Bumbacea D, Cirillo DM, Gorek Dilektasli A, et al. Risk assessment of tuberculosis in immunocompromised patients - a TBNET study. Am J Respir Crit Care Med 2014. http://dx.doi.org/10.1164/ rccm.201405-09670C.

[7] Diel R, Goletti D, Ferrara G, Bothamley G, Cirillo D, Kampmann B, et al. Interferon- $\gamma$ release assays for the diagnosis of latent Mycobacterium tuberculosis infection: a systematic review and meta-analysis. Eur Respir J 2011;37: 88-99. http://dx.doi.org/10.1183/09031936.00115110.

[8] Machingaidze S, Wiysonge CS, Gonzalez-Angulo Y, Hatherill M, Moyo S, Hanekom W, et al. The utility of an interferon gamma release assay for diagnosis of latent tuberculosis infection and disease in children. Pediatr Infect Dis J 2011;30:694-700. http://dx.doi.org/10.1097/INF.0b013e318214b915.

[9] Cattamanchi A, Smith R, Steingart KR, Metcalfe JZ, Date A, Coleman C, et al. Interferon-gamma release assays for the diagnosis of latent tuberculosis infection in HIV-infected individuals: a systematic review and meta-analysis. J Acquir Immune Defic Syndr 2011;56:230-8. http://dx.doi.org/10.1097/ OAI.0b013e31820b07ab.

[10] Tagmouti S, Slater M, Benedetti A, Kik SV, Banaei N, Cattamanchi A, et al. Reproducibility of interferon gamma (IFN- $\gamma$ ) release assays. A systematic review. Ann ATS 2014;11:1267-76. http://dx.doi.org/10.1513/AnnalSATS.201405-1880C.

[11] Chegou NN, Heyckendorf J, Walzl G, Lange C, Ruhwald M. Beyond the IFNhorizon: biomarkers for immunodiagnosis of infection with Mycobacterium 
tuberculosis. Eur Respir J 2014;43:1472-86. http://dx.doi.org/10.1183/ 09031936.00151413.

[12] Black GF, Thiel BA, Ota MO, Parida SK, Adegbola R, Boom WH, et al. Immunogenicity of novel DosR regulon-encoded candidate antigens of Mycobacterium tuberculosis in three high-burden populations in Africa. Clin Vaccine Immunol 2009;16:1203-12. http://dx.doi.org/10.1128/CVI.00111-09.

[13] Goletti D, Butera O, Vanini V, Lauria FN, Lange C, Franken KLMC, et al. Response to Rv2628 latency antigen associates with cured tuberculosis and remote infection. Eur Respir J 2010;36:135-42. http://dx.doi.org/10.1183/ 09031936.00140009.

[14] Aabye MG, Eugen-Olsen J, Werlinrud AM, Holm LL, Tuuminen T, Ravn P, et al. A simple method to quantitate IP-10 in dried blood and plasma spots. PLoS ONE 2012;7:e39228. http://dx.doi.org/10.1371/journal.pone.0039228\#s5.

[15] Syed Ahamed Kabeer B, Sikhamani R, Raja A. Comparison of interferon gammainducible protein-10 and interferon gamma-based QuantiFERON TB gold assays with tuberculin skin test in HIV-infected subjects. Diagn Microbiol Infect Dis 2011;71:236-43. http://dx.doi.org/10.1016/j.diagmicrobio.2011.07.012.

[16] Yassin MA, Petrucci R, Garie KT, Harper G, Teshome A, Arbide I, et al. Use of tuberculin skin test, IFN- $\gamma$ release assays and IFN- $\gamma$-induced protein-10 to identify children with TB infection. Eur Respir J 2013;41:644-8. http:// dx.doi.org/10.1183/09031936.00012212.

[17] Alsleben N, Ruhwald M, Rüssmann H, Marx FM, Wahn U, Magdorf K. Interferon-gamma inducible protein 10 as a biomarker for active tuberculosis and latent tuberculosis infection in children: a case-control study. Scand J Infect Dis 2012;44:256-62. http://dx.doi.org/10.3109/00365548.2011.632644.

[18] Blauenfeldt T, Heyckendorf J, Graff Jensen S, Lange C, Drabe C, Hermansen TS, et al. Development of a one-step probe based molecular assay for rapid immunodiagnosis of infection with M. tuberculosis using dried blood spots. PLoS ONE 2014;9:e105628. http://dx.doi.org/10.1371/journal.pone.0105628.

[19] Aabye MG, Ravn P, Johansen IS, Eugen-Olsen J, Ruhwald M. Incubation of whole blood at $39^{\circ} \mathrm{C}$ augments IP-10 and IFN- $\gamma$ responses to M. tuberculosis antigens. Clin Vaccine Immunol 2011. http://dx.doi.org/10.1128/CVI.00051-11.

[20] Hasday JD, Singh IS. Fever and the heat shock response: distinct, partially overlapping processes. Cell Stress Chaperones 2000;5:471-80.

[21] Cannon JG. Perspective on fever: the basic science and conventional medicine. Complementary Ther Med 2013;21:S54-60. http://dx.doi.org/10.1016/ j.ctim.2011.08.002.

[22] Kobayashi Y, Ito Y, Ostapenko VV, Sakai M, Matsushita N, Imai K, et al. Feverrange whole-body heat treatment stimulates antigen-specific T-cell responses in humans. Immunol Letters n.d. doi:10.1016/j.imlet.2014.09.014.

[23] Baronzio G, Gramaglia A, Fiorentini G. Hyperthermia and immunity. A brief overview. In Vivo 2006;20:689-95.

[24] Repasky EA, Evans SS, Dewhirst MW. Temperature matters! And why it should matter to tumor immunologists. Cancer Immunol Res 2013;1:210-6. http://dx.doi.org/10.1158/2326-6066.CIR-13-0118.

[25] Aabye MG, Latorre I, Diaz J, Maldonado J, Mialdea I, Eugen-Olsen J, et al. Dried plasma spots in the diagnosis of TB: IP-10 release assay on filter paper. Eur Respir J 2013. http://dx.doi.org/10.1183/09031936.00129412.

[26] Mori T. Specific detection of tuberculosis infection: an interferon- -based assay using new antigens. Am J Respir Crit Care Med 2004;170:59-64. http:// dx.doi.org/10.1164/rccm.200402-1790C.

[27] Ruhwald M, Dominguez J, Latorre I, Losi M, Richeldi L, Pasticci MB, et al. A multicentre evaluation of the accuracy and performance of IP-10 for the diagnosis of infection with M. tuberculosis. Tuberculosis 2011;91:260-7.
[28] Willaim C. Whitworth, Gerald H. Mazurek, Donald J. Goodwin. Assay parameters affecting variability of QuantiFERON?-tb gold in-tube assay results. C61. IMMUNODIAGNOSTICS for latent tuberculosis infection and tuberculosis, American Thoracic Society; n.d., p. A4728-A4728.

[29] Evans SS, Fisher DT, Skitzki JJ, Chen Q. Targeted regulation of a lymphocyteendothelial-interleukin-6 axis by thermal stress. Int J Hyperth 2008;24: 67-78. http://dx.doi.org/10.1080/02656730701772498.

[30] Mace TA, Zhong L, Kilpatrick C, Zynda E, Lee C-T, Capitano M, et al. Differentiation of CD8 $+\mathrm{T}$ cells into effector cells is enhanced by physiological range hyperthermia. J Leukoc Biol 2011;90:951-62. http://dx.doi.org/10.1189/ jlb.0511229.

[31] Duff GW, Durum SK. Fever and immunoregulation: hyperthermia, interleukins 1 and 2, and T-cell proliferation. Yale J Biol Med 1982:55:437-42.

[32] Lee C-T, Zhong L, Mace TA, Repasky EA. Elevation in body temperature to fever range enhances and prolongs subsequent responsiveness of macrophages to endotoxin challenge. PLoS ONE 2012;7:e30077. http://dx.doi.org/10.1371/ journal.pone.0030077.

[33] Mace TA, Zhong L, Kokolus KM, Repasky EA. Effector CD8+ T cell IFN- $\gamma$ production and cytotoxicity are enhanced by mild hyperthermia. Int J Hyperth 2012:28:9-18, http://dx.doi.org/10.3109/02656736.2011.616182.

[34] Downing JF, Martinez-Valdez H, Elizondo RS, Walker EB, Taylor MW. Hyperthermia in humans enhances interferon- $\gamma$ synthesis and alters the peripheral lymphocyte population. J Interferon Res 1988;8:143-50.

[35] Basu S, Srivastava PK. Fever-like temperature induces maturation of dendritic cells through induction of hsp90. Int Immunol 2003;15:1053-61.

[36] Ferat-Osorio E, Sánchez-Anaya A, Gutiérrez-Mendoza M, Boscó-Gárate I Wong-Baeza I, Pastelin-Palacios $R$, et al. Heat shock protein 70 downregulates the production of toll-like receptor-induced pro-inflammatory cytokines by a heat shock factor-1/constitutive heat shock element-binding factor-dependent mechanism. J Inflamm 2014;11:19. http://dx.doi.org/ 10.1186/1476-9255-11-19.

[37] Kaiser F, Steptoe A, Thompson S, Henderson B. Monocyte cytokine synthesis in response to extracellular cell stress proteins suggests these proteins exhibit network behaviour. Cell Stress Chaperones 2014;19:135-44. http:/ dx.doi.org/10.1007/s12192-013-0440-0.

[38] Föller M, Braun M, Qadri SM, Lang E, Mahmud H, Lang F. Temperature sensitivity of suicidal erythrocyte death. Eur J Clin Investigation 2010;40: 534-40. http://dx.doi.org/10.1111/j.1365-2362.2010.02296.x.

[39] Lang F, Lang E, Föller M. Physiology and pathophysiology of eryptosis Transfus Med Hemotherapy 2012;39:308-14. http://dx.doi.org/10.1159/ 000342534.

[40] Kempe DS, Akel A, Lang PA, Hermle T, Biswas R, Muresanu J, et al. Suicidal erythrocyte death in sepsis. J Mol Med 2007;85:273-81. http://dx.doi.org 10.1007/s00109-006-0123-8.

[41] Abed M, Towhid ST, Shaik N, Lang F. Stimulation of suicidal death of erythrocytes by rifampicin. Toxicology 2012;302:123-8. http://dx.doi.org/10.1016/ j.tox.2012.10.006

[42] Seyerl M, Blüml S, Kirchberger S, Bochkov VN, Oskolkova O, Majdic O, et al. Oxidized phospholipids induce anergy in human peripheral blood T cells. Eur J Immunol 2008;38:778-87. http://dx.doi.org/10.1002/eji.200737619.

[43] Yotsumoto S, Kakiuchi T, Aramaki Y. Negatively charged phospholipids suppress IFN- $\gamma$ production in $\mathrm{T}$ cells. Biochem Biophysical Res Commun 2005;338:1719-25. http://dx.doi.org/10.1016/j.bbrc.2005.10.179. 